\title{
International Law, Cultural Diversity, and Democratic Rule: Beyond the Divide Between Universalism and Relativism
}

\author{
Niels PETERSEN* \\ Max Planck Institute for Research on Collective Goods, Germany \\ petersen@coll.mpg.de
}

\begin{abstract}
The conflict between ethical universalism and cultural diversity remains a pre-eminent problem of the present international legal system. International law is in a dilemma. It cannot abstain from adopting some material values as the international community cannot be indifferent to the suppressions of citizens or certain minorities by totalitarian regimes. Yet the international legal system must not become an instrument of Western cultural imperialism by negating any cultural differences. This contribution argues that international law is a framework concept prescribing certain basic values. However, these values are not absolute and must be balanced against competing interests. In this balancing process, states have considerable political discretion. This concept will be exemplified by an analysis of the debate on the existence of a right to democratic governance in international law. It will be shown that even though international law does not require states to be democratic, it nevertheless imposes certain standards of legitimacy.
\end{abstract}

It is a commonplace among legal scholars today that the international legal order has developed from a system of co-ordination to a system of co-operation. ${ }^{\mathrm{I}}$ International law is no longer merely a neutral procedural order to co-ordinate external state conduct, but increasingly contains substantive standards addressed to the internal legal order of states. These standards call for the respect of human rights, or even impose legitimacy requirements on national governments. International law thus transports ethical values. ${ }^{2}$ Consequently, there have been some recent conceptualizations of international law that try to emphasize a universal ethical foundation of the

* Senior Research Fellow, Max Planck Institute for Research on Collective Goods, Bonn, Germany. This contribution is based on a presentation given by the author at the Second Biennial General Conference of the Asian Society of International Law, Tokyo, Japan, I-2 August 2009. I am very grateful to Christoph Engel, Stefan Kadelbach, and Monia Manaa, as well as to two anonymous reviewers, for comments and critiques, and to Brian Cooper for his excellent linguistic revision of the text.

I. Seminally, see Wolfgang Gaston FRIEDMANN, The Changing Structure of International Law (New York: Columbia University Press, I964).

2. Stefan KADELBACH, "Ethik des Völkerrechts unter Bedingungen der Globalisierung" (2004) 64 Heidelberg Journal of International Law I. 
international legal system. ${ }^{3}$ However, as the validity of ethical values is always to a certain extent dependent on cultural and social imprints, such a material charging might overstrain the global legal order. ${ }^{4}$ International law is supposed to be addressed to all nation-states around the globe. However, it is to a large extent formed by actors and legal scholars who have received their cultural imprint in the Western hemisphere. ${ }^{5}$ The accusation that an international law prescribing material values is a form of cultural imperialism ${ }^{6}$ is thus not easily dismissed. In order to confront cultural imperialism, some Asian scholars even argue that there should be a specific Asian perspective on international law. ${ }^{7}$

This contribution tries to display strategies of the international legal order that can deal with this challenge. It argues that international law cannot totally abstain from embracing material values because a purely formal system of co-ordination would be based on false premises. However, the global legal order can only provide an ethical framework that leaves sufficient room for regional and cultural diversity. This concept will be exemplified by references to the discussion on the emergence of a right to democratic governance in international law. It will be sketched out that there is no universal obligation for states to be democratic. Nevertheless, states do not have unlimited discretion with regard to their form of governance. I will proceed in four steps: after a short outline of the general problem (section I), I will propose a general solution concept (section II). There will then be a closer look at the debate on the universality of democracy in particular (section III) in order to re-analyse the debate on democratic governance through the prism of the general solution concept (section IV).

3. Notably, some strands of the constitutionalist school try to conceptualize international law from a universal ethical foundation. See Vera GOWLLAND-DEBBAS, "Judicial Insights into Fundamental Values and Interests of the International Community" in A. Sam MULLER, David RAIČ, and J.M. THURÁNSZKY, eds., The International Court of Justice: Its Future Role After Fifty Years (The Hague; Boston: Martinus Nijhoff Publishers, 1997), 327; Christian TOMUSCHAT, "International Law: Ensuring the Survival of Mankind on the Eve of a New Century" (I999) 28I Recueil des Cours Io at I3; Anne PETERS, "Compensatory Constitutionalism: The Function and Potential of Fundamental International Norms and Structures" (2006) i9 Leiden Journal of International Law 579; Erika DE WET, "The International Constitutional Order" (2006) 55 International and Comparative Law Quarterly 5I. The school of liberal legal thinking and the New Haven school also build their conceptions of international law on a universal understanding of certain values. For the former, see Anne-Marie SLAUGHTER, "International Law and International Relations Theory: A Dual Agenda" (I993) 87 American Journal of International Law 205. For the latter, see Myres S. McDOUGAL and Harold D. LASSWELL, "The Identification and Appraisal of Diverse Systems of Public Order" (I959) 53 American Journal of International Law I.

4. See Amartya SEN, The Idea of Justice (London; New York: Allen Lane, 2009), who stresses the impossibility of identifying one global just institutional order. See also Jean D'ASPREMONT, “The Foundations of the International Legal Order" (2007) I 8 Finnish Yearbook of International Law 219, who emphasizes the contingency of ethical values and thus proposes focusing on common interests instead.

5. Adamantia POLLIS and Peter SCHWAB, "Human Rights: A Western Construct with Limited Applicability" in Adamantia POLLIS and Peter SCHWAB, eds., Human Rights: Cultural and Ideological Perspectives (New York: Praeger Publishers, I979), I at 2-4.

6. See the Executive Board of the American Anthropological Association, "Statement on Human Rights" (I947) 49 American Anthropologist 539.

7. See M. SORNARAJAH, "The Asian Perspective to International Law in the Age of Globalization" (200I) 5 Singapore Journal of International and Comparative Law 284. 


\section{THE INTERNATIONAL LAW DILEMMA: ETHICAL UNIVERSALITY VS. CULTURAL DIVERSITY}

A global legal order aiming at the co-operation of states faces a serious dilemma. According to the traditional paradigm of international law, states were the only focal point of legal norms. Individuals did not factor in this system. Their presence was only an indirect one, as they were supposed to be represented by their respective governments. ${ }^{8}$ There was thus a presumption that governments acted in the interest of their citizens. However, history tells us that this assumption is flawed in many cases. In almost all regions of the world, we find situations where governments cruelly turned against their own citizenry, or a specific minority in the population. The genocides of the Jews in Germany, the Armenians in Turkey, the Tutsis in Rwanda, and the Cambodian population by the Khmer Rouge are only some examples.

The genocide during World War II in particular disposed the international community to set up a system of rights to protect citizens not only from external nations, but also from their own state. ${ }^{9}$ This introduction of material values into the international legal order posed the above-mentioned problem of cultural imperialism. The sources of human rights norms are twofold: on the one hand, they are treaty-based; on the other, they are derived from customary law. Both these sources are subject to interpretational discretion. The terms used in human rights treaties are often vague and have to be specified by international jurisprudence and international law scholarship. The identification of customary international law often depends on a rather subjective selection and evaluation of state practice that is often influenced by the political and social background of the interpreting judge or scholar. ${ }^{\text {.0 }}$

This poses a problem if legal interpretation is dominated by legal scholars with a Western cultural imprint. As ethical standards are subjective and vary between cultures, the application of universal human rights may lead to value imperialism if Western thought determines what is meant to be universally applicable. ${ }^{\text {II }}$ Yet we cannot allow states to interpret international norms according to their own liking, as this would allow governments to dispose of the material standards that are supposed to be specifically directed towards them to protect their citizens against their transgressions of power.

\section{INTERNATIONAL LAW AS A FRAMEWORK CONCEPT FOR ETHICAL VALUES}

As the structure of the problem is paradoxical, there cannot be a clear-cut logical answer. Therefore, the proposed solution will be a pragmatic one, trying to find a

8. Lassa Francis Lawrence OPPENHEIM, edited by Hersch LAUTERPACHT, International Law: A Treatise, 8th ed. (London; New York: Longmans, Green \& Co., 1955) at 737.

9. Some scholars argue that the mere fact that rights are created for the individual already establishes the need for a universal conception of human rights. See e.g., Fernando R. TESÓN, "International Human Rights and Cultural Relativism” (I985) 25 Virginia Journal of International Law 869.

ıo. Martti KOSKENNIEMI, "The Pull of the Mainstream” (I990) 88 Michigan Law Review I946 at I949-50.

II. See ONUMA Yasuaki, “Towards an Intercivilizational Approach to Human Rights" (I997) 7 Asian Yearbook of International Law 2I at 25 (noting that authoritarian governments may possess a certain legitimacy despite not fully complying with Western human rights concepts). 
middle way between the two poles of absolute universalism and radical relativism. It will be argued in this section that international law is a framework concept, which provides for an "overlapping consensus" ${ }_{22}$ setting certain limits to governmental discretion, but leaving ample room for cultural differences. ${ }^{\mathrm{I} 3}$ International law does not provide a set of standards for the positive conduct of states, but only sets negative limitations to the conduct of governments. It does not prescribe what states should do, but only imposes outer limits on their behaviour.

\section{A. Relativism and the Rejection of Hierarchy}

When we look at the human rights discourse, we will rarely find a denial that certain human rights, such as those expressed in the Universal Declaration of Human Rights (UDHR) ${ }^{\mathrm{I} 4}$, exist at all. No state will, at least not openly, claim to have the right to torture its citizens to its own liking. The justifications brought forward by authoritarian states for infringing upon certain political freedoms and liberties are in most cases not that these liberties do not exist at all, but that there are competing values which are deemed superior to the restricted freedom. In contrast, if Western states reject the concept of a right to development, the motivation behind this rejection is not that development is something undesirable, but the fear that it might compromise other goals.

The debate is thus not about the validity of individual human rights. It is rather about what concerns are legitimate in order to justify a restraint of these rights. Human rights are not, and cannot be, absolute. ${ }^{15}$ In a world of competing rights and interests, it is impossible to single out certain rights that cannot be restrained at all. ${ }^{\mathrm{I}}$ In many cases, the implementation of the rights of one individual can infringe upon the rights of a third person, or of a certain group. Even within a nation-state, there can thus be no abstract hierarchy between different rights. Rights rather have to be perceived as principles, ${ }^{17}$ whose reconciliation depends on the circumstances of each case. ${ }^{18}$

International law contains different dimensions of human rights—individual rights and group rights, political rights, social rights, and rights concerning the personal status. ${ }^{19}$

I2. John RAWLS, "The Idea of an Overlapping Consensus" (I987) 7 Oxford Journal of Legal Studies I.

I3. See also OWADA Hisashi, "Some Reflections on Justice in a Globalizing World" (2003) 97 ASIL Proceedings I8I at I9I (making a similar proposal by promoting the establishment of a common framework of public order); Onuma, supra note I I at 37 (proposing an intercivilizational approach to human rights).

I4. Universal Declaration of Human Rights, GA Res. 217A (III), UN Doc. A/8 Io (I948) [UDHR].

I 5. Yash GHAI, "Universalism and Relativism: Human Rights as a Framework for Negotiating Interethnic Claims” (2000) 2I Cardozo Law Review I095 at I099.

I6. See Mattias KUMM, "Liberale Gerechtigkeitstheorien und die Struktur der Grundrechte" in Robert ALEXY, ed., Juristische Grundlagenforschung (Stuttgart: Franz Steiner Verlag, 2005), 2 I8 at 220.

I7. The concept of individual rights as principles has been elaborated on in Robert ALEXY, A Theory of Constitutional Rights (New York: Oxford University Press, 2002) at 44-69.

I8. See Stefan KADELBACH and Thomas KLEINLEIN, "International Law-a Constitution of Mankind? Attempt at a Re-appraisal with an Analysis of Constitutional Principles" (2007) 50 German Yearbook of International Law 303 at 337-8; Niels PETERSEN, "Customary Law Without Custom? Rules, Principles, and the Role of State Practice in International Norm Creation" (2008) 23 American University International Law Review 275 at $287-8$.

I9. See Vienna Declaration and Programme of Action, World Conference on Human Rights, UN Doc. A/CONF. I 57/23 (1993). 
These rights may come into conflict with each other. ${ }^{20}$ For some of these conflicts we can observe different solutions even within the Western hemisphere. A government may, for example, want to restrict the economic liberty of its citizens in order to guarantee a certain level of material equality for the whole population, while its counterpart cherishes the idea that every individual is responsible for his or her own economic wellbeing and in turn does not care for material equality. In contrast, other conflicts reflect the specific situation of developing countries, where a government may, for example, have a legitimate interest in restricting the freedom of movement of its citizens in order to prevent an overcrowding of its cities and preserve the collective right to development.

Understood in these terms, the concept of relativism does not so much deny the existence of universal values. It denies that there exists a hierarchy between them and has a rather pluralistic understanding of the interplay between different rights and values. This is also reflected in positive international law. Most of the human rights guaranteed by the major human rights treaties, such as the two human rights covenants, ${ }^{21}$ can be restricted for particular purposes. Restrictions of the freedom of expression are, for example, possible in order to protect the interests of third persons or for the protection of national security, ordre public or public health. ${ }^{22}$ Similarly, the right to life allows for exceptions if the deprivation is not arbitrary. ${ }^{23}$

Furthermore, the covenants do not only contain provisions enabling states to actively restrict the mentioned rights. They also impose positive obligations on the parties to the covenants to protect the rights against interferences by third persons. ${ }^{24}$ This is, for example, expressed by Article 2(I) of the International Covenant on Civil and Political Rights (ICCPR), according to which states have to both respect and ensure for their populations the rights recognized by the covenant. However, if rights possess a negative as well as a positive dimension, there is considerable potential for conflict between the positive dimension of one right and the negative dimension of another. The ICCPR does not contain a provision on how to resolve such conflicts. Neither does it contain any indications on how to deal with conflicts with rights guaranteed by other human rights treaties or by custom. With the social rights of the second generation and the group rights of the third generation, the emphasis often

20. See in particular, ONUMA Yasuaki, "In Quest of Intercivilizational Human Rights: 'Universal' vs. 'Relative': Human Rights Viewed from an Asian Perspective” (2000) I Asia-Pacific Journal on Human Rights and the Law 53 .

21. International Covenant on Civil and Political Rights, I9 December I966, 999 U.N.T.S. I7I (entered into force 23 March 1976) [ICCPR]; International Covenant on Economic, Social and Cultural Rights, I9 December I966, 993 U.N.T.S. 3 (entered into force 3 January I976) [ICESCR].

22. ICCPR, supra note $2 \mathrm{I}$, art. I9(3).

23. Ibid., art. 6(I). On the notion of arbitrary deprivation, see Niels PETERSEN, "Life, Right to International Protection" in Rüdiger WOLFRUM, ed., Max Planck Encyclopedia of Public International Law (MPEPIL) (Oxford: Oxford University Press, 2008), online: MPEPIL 〈www.mpepil.com〉, para. I 5.

24. See Thomas BUERGENTHAL, "To Respect and to Ensure: State Obligations and Permissible Derogations" in Louis HENKIN, ed., The International Bill of Rights: The Covenant on Civil and Political Rights (New York: Columbia University Press, I98I), 72 at 77-8; Manfred NOWAK, UN Covenant on Civil and Political Rights: CCPR Commentary (Kehl, Germany; Arlington, Virginia: N.P. Engel, 1993) at 45, para. 20. 
lies especially on the positive dimension such that potential conflicts may arise with the negative dimension of political rights. That there are no general rules governing the resolution of these conflicts is not a failure of construction, as it would be impossible to establish an abstract hierarchy. Furthermore, the lack of precise provisions in this context respects cultural diversity. Therefore, conflicts of values cannot be resolved in the abstract, but depend on the circumstances and the cultural context of each individual case.

\section{B. Pluralism and the Margin of Appreciation Doctrine}

How does this pluralistic understanding of the relationship of concurring values work? As pointed out, international law provides a mere framework for resolving such conflicts. It provides us with a list of legitimate rights and concerns by means of the treaties that have been ratified by the respective country or the customary norms to which the latter is subject. It does not, however, give us concrete guidelines as to how to dissolve these normative conflicts-the hierarchy of competing individual and collective rights depends rather on the cultural context of each nation.

The doctrinal concept that helps us to deal with this hierarchical relativity can be modelled after the margin of appreciation doctrine, which was developed by the European Court of Human Rights (ECtHR), ${ }^{25}$ but is increasingly being applied by other international tribunals. ${ }^{26}$ The doctrine acknowledges cultural differences between states by granting the legislator of a state a margin of appreciation when reconciling conflicting rights. ${ }^{27}$ The margin of appreciation is, certainly, not unlimited, and its limits can be controlled by the respective tribunal. When we want to apply this concept to the global arena, we have to bear in mind that the cultural differences on the universal level are much more significant than in the European context, so that we have to accept a wider margin of discretion. What then are the limits of such a wide margin of discretion?

We have seen that the pre-eminent dilemma of international law is that while the system wants to protect against the exploitation of the population by its own government, it is the latter which represents the interests of the former in the international fora. The limits of the margin of discretion are therefore exceeded when the government adopts self-serving measures to the detriment of its citizens under the shield of cultural exceptionalism. Below, three criteria shall be proposed in order to test whether the discretion has been exceeded.

25. Seminally, in Handyside v. United Kingdom, Judgment of I 2 December I976, (I976) I E.H.R.R. 737 at paras. $48-50$.

26. See Yuval SHANY, “Toward a General Margin of Appreciation Doctrine in International Law?” (2005) I6 European Journal of International Law 907.

27. For an attempt to transfer the margin of appreciation doctrine to the universal level in order to cope with the problem with cultural relativism, see Eva BREMS, "The Margin of Appreciation Doctrine in the Case-Law of the European Court of Human Rights" (I996) 56 Heidelberg Journal of International Law 240 at 3ro-I2; Douglas Lee DONOHO, "Autonomy, Self-Governance, and the Margin of Appreciation: Developing a Jurisprudence of Diversity within Universal Human Rights” (200I) I 5 Emory International Law Review 391. 
First, the aim pursued by the respective government has to be legitimate. ${ }^{28}$ There are two indicators for the legitimacy of a pursued goal. On the one hand, it has to be in accordance with at least regional international norms so that it can be shown that the perception of legitimacy is at least shared by some other states. On the other hand, it has to be commonly acceptable by the affected population, i.e. there should be no direct discrimination of a certain group of citizens. ${ }^{29}$ A majority population within a state cannot suppress a minority culture in the name of cultural exceptionalism, as they would disregard exactly the same principle in the internal sphere that they are relying on vis-à-vis external critics. A state may thus be able to establish a theocracy. However, at the same time it cannot persecute religious minorities and try to extinguish differing religious practices because the freedom of religion cannot be granted merely to a considerable part of the population while denying it to others.

Second, there has to be a plausible relation between the pursuance of the aim and the restriction of a human right..$^{\circ}$ If birth control is a suitable means of preventing population growth, then such a practice may be a justified restriction on the individual right to private life in order to further the right of development of the whole citizenry. However, practices such as torture or the restriction of the freedom of expression will hardly be justified by the promotion of development, as it will be difficult to explain that there is causal relation between these different goals. Third and finally, there should not be less restrictive means of attaining the same goal.

There are some critical voices in international law scholarship complaining that the margin of appreciation doctrine leaves too much discretion to legal decision-makers and thus leads to arbitrary results. ${ }^{3 \mathrm{I}}$ However, the more diverse the context of rule application is, the less we can rely on a one-rule-fits-all approach. Strict rules applied to a complex reality quickly become overinclusive or underinclusive. Martti Koskenniemi has pointed out that, because of this fact, the indeterminacy of legal rules is a central aspect of the legitimacy of international law. ${ }^{32}$ Thus, judicial discretion has to be an inherent part of legal decision-making. In this respect, the margin of appreciation doctrine does not differ qualitatively from other problems of interpretation in international law.

In sum, international law does not contain a detailed system of ethical rules that determines every conflict of value. In balancing conflicting values, governments and legislators instead have a wide margin of appreciation. International lawyers can

28. See Paul MAHONEY, “Marvellous Richness of Diversity or Invidious Cultural Relativism?” (I998) I9 Human Rights Law Journal I at 5 (stressing the importance of the legitimacy of the aim when controlling the borders of the margin of appreciation).

29. See Eyal BENVENISTI, "Margin of Appreciation, Consensus, and Universal Standards" (I999) 3I New York University Journal of International Law and Politics 843 at 847 .

30. Compare with Patricia WIATER, Kulturpluralismus als Herausforderung für Rechtstheorie und Rechtspraxis (Baden-Baden: Nomos, 2009) at 346-7 (noting that the main instrument of the ECtHR for controlling the margin of appreciation of the Member States of the Convention is a deconstruction of the argumentation of the state authorities).

3I. Michael R. HUTCHINSON, "The Margin of Appreciation Doctrine in the European Court of Human Rights" (I999) 48 International and Comparative Law Quarterly 638 at 64I; Jeffrey A. BRAUCH, "The Margin of Appreciation and the Jurisprudence of the European Court of Human Rights: Threat to the Rule of Law" (2005) i I Columbia Journal of European Law I I3.

32. Martti KOSKENNIEMI, From Apology to Utopia: The Structure of International Legal Argument (Cambridge; New York: Cambridge University Press, 2005 reprint) at 59I. 
only control the limits of this margin of appreciation by determining whether the pursued aim is legitimate, whether there is a plausible causal relationship between the restriction of one right and the promotion of a competing right, and finally, whether less restrictive means of attaining the same goal exist.

\section{THE DEMOCRACY DILEMMA: IS THERE ROOM FOR AN ASIAN WAY?}

Even if we allow for cultural differences in balancing competing moral and human rights issues, a central question remains as to who decides what the standards for a specific state or political community are. The question of government is thus central to solving the dilemma of ethical universalism and cultural diversity. Is the mere exercise of effective control of sovereign power for a government sufficient, or is it necessary that certain minimum standards of legitimacy have to be fulfilled for a government to be allowed to raise its voice in the discourse on the relevant standards? After the end of the Cold War, some Western scholars claimed that international law required states to be democratic or that there was, at least, an emerging norm to democratic governance. ${ }^{33}$

Responding to these claims, some Asian political leaders, notably the then Prime Minister of Malaysia, Mahathir bin Mohamad, and Singapore's then Prime Minister, Lee Kuan Yew, lobbied for an Asian way in the issue of internal governance. They argued that Western democracy could not easily be transferred to Asian societies because it conflicted with Asian philosophical and religious traditions. ${ }^{34}$ In contrast to Western concepts, political societies are perceived as systems of obligations rather than a system of rights, and ethical values are more community-oriented than focused on the individual. We can assume two distinct motivations behind such an argument. First, it may be used strategically. If those persons who raise the argument also claim the power to define what Asian values are, it is not far-fetched to suspect that it is merely used as an apology for the status quo. ${ }^{35}$ However, it is also possible to adopt another reading of the debate. The rejection of "Western" democracy might also be connected to the fear that the adherence to democracy is necessarily connected to an import of Western societal values.

Is democracy then an imperative correlate to a Western tradition of rights and individualism? Historically, at least, certain evidence points in this direction. In Europe, the emergence of modern democracy is closely connected to the philosophy of the Enlightenment, which championed individual liberty and a culture of rights. ${ }^{36}$ Democracy was understood to be the best collective expression of individual freedom

33. Seminally, Thomas M. FRANCK, “The Emerging Right to Democratic Governance" (I992) 86 American Journal of International Law 46; Gregory H. FOX, "The Right to Political Participation in International Law" (I992) I7 Yale Journal of International Law 539.

34. See e.g., Mahathir bin MOHAMAD, "Agenda for a New Asia” (Keynote Address, Hong Kong, 28 October 2000), online: ASEAN 〈www.aseansec.org/2805.htm〉.

35. Michael IGNATIEFF, Human Rights as Politics and Idolatry (Princeton, NJ: Princeton University Press, 200I) at 68; Wolfgang MERKEL, Demokratie in Asien: Ein Kontinent zwischen Diktatur und Demokratie (Bonn: J.H.W. Dietz, 2003) at 9I.

36. Wolfgang KERSTING, Die politische Philosophie des Gesellschaftsvertrags (Darmstadt: Wissenschaftliche Buchgesellschaft, I994) at I I. 
because it gave every society the opportunity to determine its own fate. ${ }^{37}$ However, democracy in itself is not a perfect means of preventing domination; as it is always a rule of the majority over the minority, ${ }^{38}$ there is no guarantee that the choice of the greatest number is always reasonable. ${ }^{39}$ Democracy is thus not authority without rule, but just another form of ruling.

We must therefore find another way to justify democracy. The most obvious justification would be based on performance-democracy might be superior to autocratic forms of state because it performs better than the latter. ${ }^{40}$ There is some empirical literature in the political sciences comparing the economic performance of democracies with that of autocracies. ${ }^{4 \mathrm{I}}$ This discussion has generated evidence that democracies, on average, do better than their autocratic counterparts. The economy grows faster, employees are more efficient, and they get a bigger share of what they produce. ${ }^{42}$ However, this result only concerns the average. Autocracies have a much bigger statistical variance than democracies. If we look at the list of states that have grown most quickly between 1950 and I990, we find only one democracy among thirteen states. ${ }^{43}$ However, autocracies are not only at the top, but also at the bottom of the list: among the ten states with the weakest growth, we also find eight autocracies and only two democracies. ${ }^{44}$

How do we explain this result? Autocracies can, under certain conditions, provide favourable conditions for economic growth. They may provide a certain amount of stability, and there is less veto power to reform programmes by internal checks and balances than there often is in democratic systems. However, they have one big flaw: there is no institutional guarantee that an autocrat acts in the interest of his citizens. If he does not, it is nearly impossible to get rid of him by non-violent means. In reality, most autocrats are probably not benevolent, but rather, self-enriching. ${ }^{45}$

37. See Immanuel KANT, translated and edited by Mary GREGOR, The Metaphysics of Morals (Cambridge; New York: Cambridge University Press, I996) at 9I, para. 46:

The legislative power can belong only to the united will of the people. For since all right is supposed to emanate from this power, the laws it gives must be absolutely incapable of doing anyone an injustice. Now, if someone makes dispositions for another person, it is always possible that he may thereby do him an injustice, although this is never possible in the case of decisions he makes for himself (for volenti non fit injuria).

38. Seminally, Alexis DE TOCQUEVILLE, translated and edited by Harvey C. MANSFIELD and Delba WINTHROP, Democracy in America (Chicago: University of Chicago Press, 2000); David BROMWICH and George KATEB, eds., John Stuart MILL, On Liberty (New Haven: Yale University Press, 2003).

39. David ESTLUND, "Making Truth Safe for Democracy" in David COPP, Jean HAMPTON, and John E. ROEMER, eds., The Idea of Democracy (Cambridge; New York: Cambridge University Press, I993), $7 \mathrm{I}$.

40. Certainly, performance is not related only to economic development, but may also refer to other fields such as quality of life in general or the rule of law.

4I. The argument in this section relies on Adam PRZEWORSKI et al., Democracy and Development: Political Institutions and Well-Being in the World, I950-I990 (Cambridge: Cambridge University Press, 2000) at I42-86, which is probably the most sophisticated study in this field. See also Ian SHAPIRO, The State of Democratic Theory (Princeton, NJ: Princeton University Press, 2003) at 86.

42. Przeworski et al., supra note 4I at I66-76.

43. Ibid., at $176-7$.

44. Ibid.

45. Adam PRZEWORSKI and Fernando LIMONGI, "Political Regimes and Economic Growth" (I993) 7 Journal of Economic Perspectives 5I at 55; Herbert OBINGER, "Demokratie und Wirtschaftswachstum" 
The big advantage of democracies is thus that governments are accountable to their citizenry, which gives them incentives to act in the latter's interests. If we are thus faced with a decision about the form of state behind the Rawlsian veil of ignorance, ${ }^{46}$ we would probably opt for a democracy because we would not know what kind of autocrat we would get-and the odds are in favour of not getting a good one.

However, real-life decisions are not made behind the veil of ignorance. While democracy is, based on its performance, preferable in principle, this primacy is not absolute. Exceptions are well justified. Modernization theory reminds us that democracy is particularly unstable in countries with a low level of economic development. ${ }^{47}$ Furthermore, some societies may not have the necessary ethnic or social cohesion that is a necessary ingredient for a democracy to be stable..$^{8}$ In such situations, autocratic rule may well be justified if it provides the necessary stability and acts in the interest of its population.

Although stemming from the historical context of the Enlightenment, the concept of democracy is thus not necessarily interlinked with Western philosophical traditions. The main reason for democratic procedures is that they hold political actors accountable and contribute to ensuring that governments act in the interest of their populations. It is thus only a procedural framework that is flexible enough to accommodate different value systems and cultural traditions. ${ }^{49}$ Furthermore, democracy is not an end in itself, but only a means to attain certain goals. Democracy is thus not an absolute concept. Instead, exceptions are possible if there are reasonable justifications.

\section{THE LEGAL DEBATE ON DEMOCRACY IN INTERNATIONAL LAW}

The tension between universalism and relativism can also be found in the early legal discourse on democracy. On the one hand, there is a universalist position that observes the emergence of a right to democratic governance. ${ }^{50}$ The unspoken, but

(200I) 8 Zeitschrift für Internationale Beziehungen 32I at 323; Thomas CAROTHERS, “The 'Sequencing' Fallacy" (2007) I 8 Journal of Democracy I2 at I4.

46. John RAWLS, A Theory of Justice, rev. ed. (Cambridge, MA: Belknapp Press, I999) at IO-I 5.

47. See Seymour Martin LIPSET, "Some Social Requisites of Democracy: Economic Development and Political Legitimacy” (1959) 53 American Political Science Review 69; Larry DIAMOND, "Economic Development and Democracy Reconsidered" in Gary MARKS and Larry DIAMOND, eds., Reexamining Democracy: Essays in Honor of Seymour Martin Lipset (Newbury Park, CA: Sage Publications, 1992) at 93; Adam PRZEWORSKI and Fernando LIMONGI, "Modernization: Theories and Facts" (I997) 49 World Politics I 55 at I77.

48. Cf. Adrian KARATNYCKY, "The Decline of Illiberal Democracy" (I999) Io Journal of Democracy I I 2; Andrew REYNOLDS, “Constitutional Medicine” (2005) I 6 Journal of Democracy 54.

49. Jürgen HABERMAS, "Zur Legitimation durch Menschenrechte" in Jürgen HABERMAS, Die postnationale Konstellation, 5th ed. (Frankfurt: Suhrkamp Verlag, I998), I70 at I86.

50. See e.g., Franck, supra note 33; Fox, supra note 33; Christine CERNA, "Universal Democracy: An International Legal Right or the Pipe Dream of the West?" (I995) 27 New York University Journal of International Law and Politics 289; David WIPPMAN, "Defending Democracy Through Foreign Intervention" ( I997) I9 Houston Journal of International Law 659 at 665-8; Roland RICH, "Bringing Democracy into International Law" (200I) I 2 Journal of Democracy 20 at 2 I; Jan WOUTERS, Bart DE MEESTER, and Cedric RYNGAERT, "Democracy and International Law" (2003) 34 Netherlands Yearbook of International Law I37; Jude IBEGBU, Right to Democracy in International Law (Lewiston: Edwin Mellen Press, 2003) at I4I-205; Dodzi KOKOROKO, "Souveraineté étatique et 
underlying, assumption of this position is that democracy is the right form of state for every state in all conceivable historical circumstances. On the other hand, we find the relativist position that claims that state sovereignty is an obstacle to all rules of international law concerning the internal organization of states. This position was most prominently expressed in the Nicaragua judgment of the International Court of Justice, where the Court declared that adherence to any particular doctrine could not constitute a violation of customary international law. Any other position would "make nonsense of the fundamental principle of State sovereignty". ${ }^{5 \mathrm{I}}$ There are different strands of arguments trying to justify the universalist position. In the following, I will highlight two of them in order to show that the universalist interpretation of the development that the arguments focus on is not mandatory. On one hand, I will refer to the people's right to self-determination. On the other hand, I will analyse the right to political participation expressed in the ICCPR and the UDHR..$^{52}$

\section{A. The Internal Right to Self-Determination}

With its incorporation in I966 into the common Article I of the two human rights covenants, ${ }^{53}$ the principle of self-determination received an internal dimension. ${ }^{54}$ It attributes to every people, inter alia, the right freely to determine their political status. However, one of the big conceptual questions in this respect concerns the content of political self-determination. There are some authors who argue that political self-determination necessarily implies an obligation for states to be democratic. ${ }^{55}$

principe de légitimité démocratique" (2003) I6 Revue québécoise de droit international 37 at 40; Tom J. FARER, "The Promotion of Democracy: International Law and Norms" in Edward NEWMAN and Roland RICH, eds., The UN Role in Promoting Democracy: Between Ideals and Reality (Tokyo; New York: United Nations University Press, 2004), 32 at 32; Juliane KOKOTT, "Souveräne Gleichheit und Demokratie im Völkerrecht" (2004) 64 Heidelberg Journal of International Law 5I7 at 526-7; Attila TANZI, "Remarks on Democracy in Contemporary International Law" 6I La Comunità internazionale (2006) 289; Christian PIPPAN, “Gibt es ein Recht auf Demokratie im Völkerrecht?” in Erwin RIEFLER, ed., Sir Karl Popper und die Menschenrechte (Frankfurt: Lang, 2007), I I9 at I37-60.

5I. Case Concerning the Military and Paramilitary Activities in and Against Nicaragua (Nicaragua v. United States of America), Judgment of 27 June I986, [1986] I.C.J. Rep. I4 at I33, para. 263.

52. It has to be noted, however, that there are also more nuanced analyses that try to find solutions beyond the classic democracy-autocracy-dichotomy. See Susan MARKS, The Riddle of All Constitutions: International Law, Democracy, and the Critique of Ideology (Oxford: Oxford University Press, 2000) (proposing a concept of democratic inclusion, which is supposed to guide the creation of new norms and the interpretation of existing norms of international law); Jean D'ASPREMONT, L'Etat Non Démocratique en Droit International: Étude Critique du Droit International Positif et de la Pratique Contemporaine (Paris: Pedone, 2008) (arguing that international law contains a minimum principle of electoral democracy while allowing for a number of persistent objectors and proposing a differentiated system of legal consequences with regard to illegitimate regimes); Niels PETERSEN, "The Principle of Democratic Teleology in International Law" (2008) 34 Brooklyn Journal of International Law 33 (arguing that international law contains a teleological principle, according to which there is no immediate right to democratic governance, but an obligation to develop towards democracy).

53. ICCPR, supra note $2 \mathrm{I}$, and ICESCR, supra note $2 \mathrm{I}$.

54. Antonio CASSESE, "The Self-Determination of Peoples" in Henkin, supra note 24, 92 at 97; Christoph GUSY, "Selbstbestimmung im Wandel: Von der Selbstbestimmung durch den Staat zur Selbstbestimmung im Staat” (I992) 30 Archiv des Völkerrechts 385 at 405 .

55. Antonio CASSESE, Self-Determination of Peoples: A Legal Reappraisal (Cambridge; New York: Cambridge University Press, I995) at 3II; Juan Francisco Escudero ESPINOSA, "Hacia una intervención armada en favor de la democracia?: El 'precedente' de Haití" (I996) I2 Anuario de derecho internacional 297 at 344-56; Allan ROSAS, "Internal Self-Determination" in Christian 
The argument tries to establish a logical relationship between democracy and selfdetermination. If political self-determination is exercised by the people and not by the government, then, so the argument goes, every political decision has to be attributable to the people. Such an attribution can only be obtained through democratic means. ${ }^{56}$ However, this argument is based on problematic premises. ${ }^{57}$ It does not differentiate between the act of creating a political system and the content of the political system itself-between the pouvoir constituant and the pouvoir constitué. ${ }^{8}$ The right to self-determination only relates to the former, and not necessarily to the latter. It is not inconceivable that citizens would deliberately choose to be governed by authoritarian rule. ${ }^{59}$

In the literature, two solutions to this dilemma are discussed. The first proposal tries to formally distinguish between the establishment of a political system and the political system itself. The right to self-determination only extends to the choice of the political system. If the citizens choose a system that is non-democratic, they have, by this act, exhausted their right to self-determination. ${ }^{60}$ However, this view cannot explain why the expression of a collective will at a random point in time should eternally determine the content of self-determination. Popular votes are historically contingent. Over time, the composition of the citizenry changes-as may their preferences. To relate the right to political self-determination to one singular historical event thus seems to be arbitrary.

The second solution is discussed by Gregory Fox and Georg Nolte in their seminal article on "intolerant democracies" ${ }^{61}$ Fox and Nolte argue that it is justified to ignore the results of a democratic election in order to prevent anti-democratic forces from coming to power and thus eroding democracy. They claim that democracy finds its limits where its very foundations are endangered. This view has, however,

TOMUSCHAT, ed., Modern Law of Self-Determination (Dordrecht; Boston: Martinus Nijhoff Publishers, I993), 225 at 24I-6; Patrick THORNBERRY, "The Democratic or Internal Aspect of Self-Determination with Some Remarks on Federalism" in Tomuschat, IOI at I34-7; Linos-Alexander SICILIANOS, “Les Nations unies et la démocratisation de l'Etat: nouvelles tendances" in Rostane MEHDI, ed., La contribution des Nations unies à la démocratisation de l'Etat (Paris: Pedone, 2002), I 3 at 24; Daniel THÜRER, "Self-Determination" in Rudolf BERNHARDT, ed., Encyclopedia of Public International Law, Vol IV (Amsterdam: North-Holland, 2000), 364 at 372.

56. Rosas, supra note 55 at 229; Sicilianos, supra note 55 at 24.

57. Compare with Russell A. MILLER, "Self-Determination in International Law and the Demise of Democracy?" (2003) 4I Columbia Journal of Transnational Law 60I (critiquing the argument on the necessary relationship between democracy and self-determination from a historical perspective).

58. See also Jean D'ASPREMONT, "Legitimacy of Governments in the Age of Democracy" (2006) 38 New York University Journal of International Law and Politics 877 (critiquing the monolithic conception of legitimacy often found in international law scholarship and arguing that there should be a distinction between a legitimacy of origin and a legitimacy of exercise).

59. See Jürgen GEBHARDT, "Das Demokratische Prinzip und die moderne politische Ordnung” in André KAISER and Wolfgang LEIDHOLD, eds., Demokratie-Chancen und Herausforderungen im 2 I Jahrhundert (Münster: LIT Verlag, 2005), I9 at 28 (highlighting that there are several historical examples where citizens opted for an authoritarian rule).

6o. Karl DOEHRING, "Demokratie und Völkerrecht" in Hans-Joachim CREMER, Thomas GIEGRICH, and Dagmar RICHTER, eds., Tradition und Weltoffenheit des Rechts: Festschrift für Helmut Steinberger (Berlin: Springer, 2002), I 27 at I 29.

6I. Gregory H. FOX and Georg NOLTE, "Intolerant Democracies” (I995) 36 Harvard International Law Journal I. 
a predisposition towards democracy. ${ }^{62}$ As no derogations from democracy are possible, it implies that democracy is the best form of state for all states, all cultural environments, and all socioeconomic circumstances. However, the political science literature on democratization theory suggests that the effectiveness of democracy depends on several preconditions-such as a certain level of socioeconomic development, the dispersion of power resources, or social and cultural cohesion. ${ }^{63}$

This does not mean, though, that the internal dimension of the right to selfdetermination does not contain any standards regarding the form of government. If it was solely left to the government to decide the design of the political system, then self-determination of peoples would be no different from the principle of state sovereignty and would thus lose any independent value. ${ }^{64}$ This reasoning is supported by the Friendly Relations Declaration of the United Nations (UN) General Assembly, according to which the right to self-determination presupposes "a government representing the whole people belonging to the territory without distinction as to race, creed or color". ${ }^{65}$ Consequently, not every form of government is compatible with self-determination. Rather, the government has to be representative. Excluded are governments that only represent particularistic interests. Representation does not, however, necessarily mean that elections have to be held. It may also be in the form of government in the public interest, or government for the people.

\section{B. The Right to Political Participation in International Law}

The second approach tries to trace certain signs that point towards a universal principle of democracy in the international paper practice-that is, international treaties and resolutions of the UN General Assembly. ${ }^{66}$ The principal argument refers to the right to political participation, which is contained in the $\mathrm{UDHR}^{67}$ and the ICCPR. ${ }^{6}$ According to Article 2I of the UDHR, "[e]veryone has the right to take part in the government of his country, directly or through freely chosen representatives". Similarly, Article 25 of the ICCPR guarantees genuine and periodic elections, which shall express the will of the electorate.

Considering that the ICCPR has been ratified by more than three-quarters of the members of the international community and that the UDHR is one of the principal documents of international human rights law, ${ }^{69}$ one can argue that the right to political participation has become part of customary law as well. If one then takes a

62. See Martti KOSKENNIEMI, “'Intolerant Democracies': A Reaction” (I996) 37 Harvard International Law Journal 23I at 232-3.

63. See supra notes 47 and 48 .

64. James CRAWFORD, “The Rights of Peoples: 'Peoples' or 'Governments'?” in James CRAWFORD, ed., The Rights of Peoples (Oxford: Clarendon Press; I988), 55 at 56.

65. Declaration on Principles of International Law Concerning Friendly Relations and Co-operation Among States in Accordance with the Charter of the United Nations, GA Res. 2625 (XXV)(I970).

66. See supra note 50.

67. UDHR, supra note I4, art. $2 \mathrm{I}$.

68. ICCPR, supra note $2 \mathrm{I}$, art. 25 .

69. There are even some scholars who argue that the UDHR as such has become part of customary international law. See Humphrey WALDOCK, "Human Rights in Contemporary International Law and the Significance of the European Convention” (I965) i I International and Comparative Law Quarterly 
further step and argues that the right to political participation necessarily involves multiparty elections, ${ }^{7 \circ}$ it seems that political participation can only be meaningfully exercised in a democracy.

However, this claim requires that the right to political participation be conceived as an absolute right. If you follow the conception elaborated in this contribution, then the conclusion that there is an absolute right to political participation is not mandatory. Rather, the right has to be balanced against competing rights and interests. Such competing interests might be economic development or political stability, in particular if a country lacks the necessary social, religious, and ethnic cohesion that may be necessary for a stable democracy. ${ }^{7 \mathrm{~T}}$ They will rarely be permanent obstacles to democracy, but they may be temporary reasons against the immediate introduction of a democratic system.

\section{The Limits to Autocratic Government}

In order to determine the limits of potential non-democratic governments in the public interest, we can apply the test that we have developed in the context of our general framework. ${ }^{72}$ Therefore, autocratic regimes may be justified if they provide a certain stability that would be in danger if electoral institutions were established. There have to be plausible reasons that an autocratic form of state is better suited in the concrete situation to attain these goals. One reason could be, for example, that a democracy would be highly unstable because of significant ethnic cleavages in the respective state. The criterion that there should not be less restrictive means of attaining the same end is inapplicable for norms of a binary character that deal with an either-or. In particular, we should not be tempted to think that "some" elections are always better than no elections, as it is exactly the essence of sequentialist concepts that electoral institutions are especially destabilizing if they are not accompanied by certain counter-majoritarian institutional safeguards. ${ }^{73}$

Therefore, international law only sets up a framework, leaving room for different cultural conceptions of political order and different social circumstances, for which an autocratic rule might sometimes be more appropriate than an unstable democracy. However, democracy is the benchmark, and alternative modes of government bear the burden of justification. If a non-democratic government claims that it governs in the interest of the people, then it has to justify why a deviation from the democratic standard is necessary in this particular case.

Supplement I at I5; Louis B. SOHN, “The Human Rights Law of the Charter" (I977) I2 Texas International Law Journal I 29 at I33.

70. See Karl Josef PARTSCH, "Freedom of Conscience and Expression, and Political Freedoms" in Henkin, supra note 24, 209 at 240; Gregory H. FOX, "The Right to Political Participation in International Law" in Gregory H. FOX and Brad R. ROTH, eds., Democratic Governance and International Law (New York: Cambridge University Press, 2000), 48 at 57-9; Nowak, supra note 24 at art. 25, para. 20. But see also Jure VIDMAR, "Multiparty Democracy: International and European Human Rights Law Perspectives" (20IO) 23 Leiden Journal of International Law 209 at 2I6-I 8 (critiquing this position).

7I. On interests that potentially run counter to a right to democracy, see section III.

72. See section II(B).

73. See Philippe C. SCHMITTER and Javier SANTISO, "Three Temporal Dimensions to the Consolidation of Democracy" (I998) I9 International Political Science Review 69. 


\section{CONCLUSION}

The conflict between ethical universalism and cultural diversity is still a pre-eminent problem of the present international legal system. ${ }^{74}$ We have seen in the preceding analysis that international law tries to find a middle ground between these two poles: it can neither abstain from establishing any ethical values as the international order has developed into a system of co-operation, in which citizens are also supposed to be protected against their own government; nor can it impose a uniform system of ethical values on a world that is still characterized by a great deal of cultural diversity. Instead, international law only establishes an ethical framework in the sense of a Rawlsian overlapping consensus. ${ }^{75}$ In order to implement the concept, it is not necessary to change the formal texts and sources of international law. We only have to reinterpret them. Reading certain provisions with moral content in a less universalist way helps us to relieve some of the tensions between these values and more relativist norms, such as state sovereignty, that are inherent in positive international law.

The concept is based on the idea that rights are rarely absolute. Rights and values can come into conflict with each other, and the resolution of these conflicts depends on a balancing of the circumstances of each individual case. In performing this balancing, states have a certain margin of discretion. The discussion of the existence of a principle of democratic governance is an excellent illumination of this concept. International law does not require all states to adopt Western-style democracy, but it contains certain elements of legitimacy: sovereign rule does not necessarily have to be exercised by the people, but it has to serve at least the interest of the people. This principle prevents governments from exploiting their citizens under the shield of state sovereignty and in the name of cultural exceptionalism.

74. Owada, supra note $\mathrm{I}_{3}$ at $\mathrm{I} 88$.

75. See Rawls, supra note I2. 